\title{
FIRM \\ COMPETITIVENESS \\ DETERMINANTS: \\ RESULTS OF A PANEL \\ DATA ANALYSIS
}

TIBOR LALINSKY 
(c) National Bank of Slovakia

www.nbs.sk

Imricha Karvaša 1

81325 Bratislava

research@nbs.sk

December 2013

ISSN $1337-5830$

The views and results presented in this paper are those of the authors and do not necessarily represent the official opinion of the National Bank of Slovakia.

All rights reserved. 


\title{
Firm competitiveness determinants: results of a panel data analysis ${ }^{1}$
}

\author{
Working paper NBS
}

Tibor Lalinsky²

\begin{abstract}
This paper combines results of a questionnaire survey with firm level data in order to better explain firm competitiveness. To do this, survey-based information about perceived factors is used to improve explanatory power of quantitative factors. Results from the firm level panel data model confirm that most of the top individual, sector-specific and macro factors of perceived company competitiveness are statistically significant. Different size of the effect across considered competitiveness indicators (proxied by indicators of profitability, productivity, and export performance and market share) suggests that appropriate policy measures aiming at higher overall competitiveness may vary depending on preferred definition of competitiveness. From among the factors we find that perceived impact of energy costs, EU membership and developed consumer sectors count among the most influential ones.
\end{abstract}

JEL classification: D22, L25

Key words: competitiveness, qualitative factors, firm-level data, panel data

Downloadable at http://www.nbs.sk/en/publications-issued-by-the-nbs/working-papers

\footnotetext{
${ }^{1}$ The publication reflects valuable comments made by participants of the Bratislava Economic Meeting 2012, the Compnet meeting at the European Central Bank and the research seminar at the National Bank of Slovakia.

${ }^{2}$ Research Department, NBS, tibor.lalinsky@nbs.sk .
} 


\section{INTRODUCTION}

The recent economic and debt crisis troubling the euro area has intensified discussions on causes and roots of countries' and firms' competitiveness. Missing consensus over a common competitiveness measure complicates competitiveness analysis and makes policy reaction less adequate. Available literature differs relatively widely in terms of an appropriate proxy for company competitiveness indicator. Competitiveness is usually measured by variables related to company productivity, profitability, export performance and/or market share.

These proxies for competitiveness are determined by various factors. Syverson (2010) reviewed impact of a number of company productivity determinants. A meta-analysis based on a large number of studies focused on financial performance was published by Capon et al. (1990). Nwachukwu and Oseghale (2010) concentrated on firm profitability factors in small businesses. Zou and Stan (1998) studied available findings on factors of export performance. A more recent study has been published by Nazar and Saleem (2009), who took closer look at small and medium enterprises' export performance. Taking into account findings from the mentioned meta-analyses one arrives to a relatively large number of potential exogenous and endogenous variables.

An important common characteristic of all four above mentioned competitiveness indicators is a significant time persistence. The dynamic nature of the problem requires application of more advanced regression methods, for instance GMM estimation that is used in most of the current firms' performance related studies. Andersson et al. (2007) analysed firm productivity in relation to firms' trade performance. Feldkircher at al. (2010) used GMM approach to identify determinants of profit margins and concentration ratios in Central, Eastern and Southeastern Europe. Serrasqueiro (2009) applied the method in order to find determinants of company operational return on assets in Portugal. Stephan and Tsapin (2008) studied determinants of price-cost margin and return on assets in Ukraine.

A common feature of the available literature is that it looks mainly on the degree of macro factors' effects and it studies cross-country differences. This is caused by relatively low quality and availability of detailed firm level variables. An efficient way to gain comparable individual company data is to run a questionnaire survey. An import step towards deeper analysis of firm level determinants of performance in European firms was implementation of the EFIGE ${ }^{3}$ survey. Results of the survey served as inputs for several studies. The most interesting applications of EFIGE survey results are exploring benefits of combination of a questionnaire survey data with firm level financial data. For example, findings published by Navaretti et al. (2011) confirm positive relationship between export performance and size of the firm, its productivity, ability to innovate and skill intensity of its workforce. Anos-Casero and Udomsaph (2009) combined BEEP ${ }^{4}$ survey and firm level data. Using an OLS approach, they found that infrastructure and governance made the largest contributions to total factor

${ }^{3}$ European Firms in a Global Economy. The survey was part of the project led by Bruegel and financially supported by European Commission. See www.efige.org for more information.

${ }^{4}$ Business Environment and Enterprise Performance Survey was conducted by the World Bank in 2002 and 2005 in Central and Eastern European (CEE) countries, Russia and Turkey. 
productivity growth in CEE countries, Russia and Turkey. Neither this study nor most of the firm-level studies do incorporate data on Slovak companies into their analyses.

Few exemptions include supranational analyses of company performance or competitiveness. Rutkowski (2006) concentrates on impact of inward FDI in Central and Eastern European countries and confirms that they strengthen company profitability and domestic market concentration. Sabarwal and Terrell (2008) explore gender effect on productivity and profitability of Central and Eastern European companies. Using firm level data for 63 countries extracted from the World Bank Enterprise Survey, Dabla-Norris et al. (2010) find that innovation is crucial for firm performance and its effect on productivity is significantly larger in countries with well-developed financial markets. Ospina and Schiffbauer (2010) use the same database to find that competition increases productivity.

Most of the studies incorporating Slovak firm level data are based on a cross-section analyses and ordinary least squares estimations. Some of the more recent publications implement a dynamic panel data approach. Stojcic et al.(2011) study impact of innovation activities on company's market share in several Central and Eastern European countries including Slovakia. Their results indicate that the behaviour of firms in these economies does not differ significantly and the competitiveness of firms is enhanced by higher cost efficiency, productivity of labour and investment.

Having access to Slovak firm-level financial data and results of a competitiveness related survey, we try to fill in the gap in the literature. Besides macro and industry level factors, the analysis presented in the following sections considers several quantitative, but also qualitative firm-level competitiveness factors. The main aim of the paper is to assess the impact of competitiveness factors identified in a survey among top Slovak companies (Lalinsky 2008). To a large extent we are motivated by the above mentioned EFIGE project, its survey and related analyses.

Several analyses indicate that leading Slovak companies are competitive, or at least highly profitable. Erste Group (2010) shows that Slovakia has one of the most efficient nonfinancial corporate sectors. Profitability of Slovak non-financial corporations measured by return on capital remained the highest in the EU even during the economic crisis. However, inadequate space in available literature is devoted to cross-country differences in determinants of profitability or productivity within the euro area.

The analysis presented in this paper tries to shed more light on causality of Slovak firm-level competitiveness, more precisely profitability, productivity, export performance and market share. The second section focuses on methodology and choice of estimation method. The third section describes data sources and its basic statistics. The fourth section presents main results and the final section summarizes key findings.

\section{Methodology}

Given the missing consensus on a common indicator of company competitiveness, we consider several indicators of profitability, productivity, export performance and market share, that serve as proxies for competitiveness. The explained variables belong to a group 
of economic indicators that are persistent in time. ${ }^{5}$ Therefore the analysed problem can be expressed in a form of a dynamic specification with lagged dependent variable. More precisely, the following linear dynamic panel model with individual effects is estimated:

$$
y_{i t}=\gamma y_{i, t-1}+\beta_{1} x_{i t}+\beta_{2} Z_{i}^{\prime}+\alpha_{i}+\varepsilon_{i t},
$$

where $y_{i t}$ represents available profitability, productivity, export performance and market share indicators of a company $i$ in time $t$, that are assumed to be dependent on their lagged values $y_{i, t-1}$, quantitative frim-level variable $x$ of the company $i$ in time $t$ and a matrix of qualitative competitiveness factors $Z_{i .}^{\prime}$ Finally, $a_{i}$ is a company individual effect and $\varepsilon_{i t}$ represents error term.

Taking into account the above mentioned model specification with lagged dependent variable and following Baltagi (2005), one should be aware of possible significant bias of estimates based on ordinary least squares, fixed effect or random effect estimators. ${ }^{7}$ A natural approach to overcome the main drawbacks of these estimators in this setting is to use instrumental variable (IV) or general method of moments (GMM) estimator. Similarly to number of other recent studies, this study also applies GMM estimator.

GMM estimator proposed by Arellano and Bond (1991) treats the model as a system of equations, one for each time period. The equations differ in their instrument (moment) condition sets. The predetermined and endogenous variables in first differences are instrumented with suitable lags of their own levels. Strictly exogenous regressors, as well as any other instruments, enter the instrument matrix in first differences. However, in cases where we find persistence of the dependent variable and the number of cross-sections is not particularly high, Blundell and Bond (1998) conclude that the above mentioned GMM estimator (also called difference GMM) may not be very efficient, given that the instruments may not be valid. To solve this problem, they propose system GMM estimator, considering a system of variables at levels and in first differences. But the system GMM, which estimates the equation jointly in levels and in first differences, significantly increases the number of instruments. In our case, working with limited cross-section dimension, number of instruments would easily approach or exceed number of companies and undermine validity or strength all the instruments. Therefore, presented results are based on difference GMM. ${ }^{8}$ Using the GMM estimator is helpful in several areas. It allows eliminating non-observable individual effects, effectively controls endogenity, allows greater control of possible

\footnotetext{
${ }^{5}$ The correlation coefficient between the current and lagged value of our dependent variables varied between 0,96 and 0,99 .

6 All variables except dummy variables representing qualitative competitiveness factors were expressed in logarithms. All time invariant variables were undifferenced and kept constant for the entire period.

7 Several studies confirmed that OLS estimates led to biased and inconsistent estimates due to correlation between the lagged dependent variable and the error term. Sevestre and Trognon (1985) argue that the bias can be relatively large. Random effect estimates are also biased because individual-specific error is correlated with the lagged dependent variable. Judson and Owen (1999) found that the bias in the fixed effect estimator bias increases with $\delta$ and decreases with $T$, but it can be sizeable ( $20 \%$ of the true value of the coefficient), even for large $T(T=30)$.

${ }^{8}$ More precisely, we have applied the two-step difference GMM estimator with asymptotic robust standard errors.
} 
collinearity among the independent variables and keeps in check the effects of possible omission of explanatory variables. ${ }^{9}$

Results based on the GMM estimator are considered robust under the two conditions: validity of the instruments and non-existence of second order autocorrelation in residuals (Arellano and Bond 1991). In the next section we report results for all specifications, in which Hansen J statistic's $p$-value ${ }^{10}$ was not rejected at the $5 \%$ level of significance, unless otherwise stated. At the same time, results of tests for the existence of first and second order autocorrelation are taken into account. Results passing Arrelano-Bond test for second order autocorrelation of residuals at the $5 \%$ level are reported, unless otherwise stated.

Starting with relatively large number of available variables, several approaches to identify statistically significant variables are examined. In the first phase, four baseline models are identified (one for profitability, one for productivity, one for export performance and one for market share). Each of these models features different dependent variable proxying for competitiveness and lagged dependent and quantitative explanatory variables. The identification starts by using all quantitative variables (listed in the Annex 2). All possible combinations of quantitative variables are tested, but the final specifications also depend on a true data availability (across companies and time). ${ }^{11}$ In the second phase, the selected models are extended by all top 15 competitiveness factors, and then separately by top five company, top five sectoral and top five macro-level competitiveness factors identified by a survey. However, the coefficients of the explanatory variables are not significant for any of the wider specifications. ${ }^{12}$ Finally, we gradually extend the four baseline models with basic company characteristics and competitiveness factors and find statistically significant variables determining company competitiveness. Results are presented in section 4.

\section{DATA DESCTRIPTION}

The paper draws on selected balance sheet and financial data of the largest companies in Slovakia and various qualitative firm-level, sectoral and macro-level characteristics. The balance sheet and financial data comes from the "Non-financial corporations' database", published by TREND Analyses. It offers individual annual data covering the period since 1993. The estimates reported in the following sections are derived using economic data on the top 90 Slovak companies that participated in the survey. We only use the results from the period $2001-2009$, where the highest numbers of observations are encountered. ${ }^{13}$

\footnotetext{
${ }^{9}$ All the reported estimates were obtained using xtabond2 module for Stata (developed by Roodman 2006), which in addition to the original xtabond estimator (by Arellano and Bond 1991), includes a finite-sample correction to the two-step covariance matrix derived by Windmeijer (2005). However, xtabond2 does not allow for direct inclusion of time invariant variables (i. e. already differenced ones) as xtabond does. So, the time invariant variables need to be undifferenced before applying xtabond2 estimator.

${ }^{10}$ Xtabond2 reports Hansen $\mathrm{J}$ test, in the case of the two-step estimation. Under Hansen $\mathrm{J}$ test the joint null hypothesis is that the instruments are valid, i.e. uncorrelated with the error term and that the excluded instruments are correctly excluded from the estimated equation.

${ }^{11}$ Using unbalanced panel, some specifications may have insufficient number of observation.

${ }^{12}$ Results of these estimates are called preliminary and they are presented in Annex 3.

${ }^{13}$ Besides quantitative economic data the TREND Analyses' database provides information on some qualitative data: prevalent industry, accounting year (calendar or other) and share of foreign capital.
} 
The sample we analyse covers predominantly the period of economic upturn followed by a steep decline in the overall activity. The annual real GDP growth accelerated from $3.5 \%$ in 2001 to $10.5 \%$ in 2007. In 2008, in a response to the global drop in international trade Slovak economic growth decelerated and in 2009 real GDP fell by $4,9 \%$. Behaviour of the surveyed firms was undoubtedly influenced by the prevailing economic boom. However, our robustness tests (considering the pre-crisis period separately) do not indicate any major changes to the impact competitiveness factors. In order to maintain our specifications as robust as possible, presenting the full sample results remains our preferred option.

Majority of qualitative data describing corporate competitiveness come from a questionnaire survey undertaken in 90 large companies (based on total revenue). ${ }^{14}$ The respondents were asked to assess impact of 73 potential factors affecting their competitiveness. The factors referred to 31 company-specific, 17 sectoral and 25 macro-level factors. For each factor respondents were asked to evaluate its current state, its effect on present competitiveness and its effect on assessed future competitiveness of the company. The current states were assigned values 1, 2 or 3 according to the perceived level.

In order to narrow down the number of factors and their impact to a value suitable for an econometric analysis, only data on top five company, top five sectoral and top five macrolevel factors were considered for the quantitative analysis. ${ }^{15}$ Managers of the top Slovak companies in general assigned the highest importance to the management and leadership related factors. More details about the survey and its results were published in Lalinsky (2008).

\section{Table 1 List of main competitiveness factors identified by the survey} (perceived average current level of the factor in parenthesis)

\begin{tabular}{|c|c|c}
\hline Company factors & Sectoral factors & Macro-level factors \\
\hline \hline $\begin{array}{c}\text { Professionalism of management (2.5) } \\
\text { Quality of company management } \\
(2.42)\end{array}$ & $\begin{array}{c}\text { Availability of experienced managers } \\
(1.81)\end{array}$ & EU membership (2.51) \\
\hline $\begin{array}{c}\text { Orientation on cost/price reduction } \\
(2.47)\end{array}$ & $\begin{array}{c}\text { Supply of an adequately educated }(2.35) \\
\text { workforce }(1.77)\end{array}$ & Euro adoption in Slovakia (2.48) \\
\hline $\begin{array}{c}\text { Efficiency of company leadership } \\
(2.43)\end{array}$ & $\begin{array}{c}\text { Nature of competitive advantage } \\
(2.06)\end{array}$ & Exchange rate stability (1.98) \\
\hline $\begin{array}{c}\text { Extent of communication technology } \\
\text { utilisation }(2.72)\end{array}$ & $\begin{array}{c}\text { Existence of developed consumer } \\
\text { sectors (2.20) }\end{array}$ & $\begin{array}{c}\text { Quality of transportation } \\
\text { infrastructure (1.79) }\end{array}$ \\
\hline \hline \begin{tabular}{l} 
Source: Lalinský (2008). \\
\hline
\end{tabular}
\end{tabular}

${ }^{14}$ The survey has targeted top 200 Slovak companies. The author received 93 responses, out of which 90 were from companies represented in the firm-level economic database published by TREND Analyses, used as a source for financial and balance sheet data. Age of the all analysed companies (originating from both industry and services sectors) varied between 2 to 50 years with median exceeding 11 years.

${ }^{15}$ In cases, when none of the top five company, sectoral or macro factors were statistically significant, additional company, sectoral or macro-level factors were used. They included corporate relationships with other companies at the company level, availability of quality domestic suppliers at the sectoral level, and quality telecommunication infrastructure at the macro level. 
Several additional qualitative data were taken from the Business Register of the Slovak Republic. These were information regarding a company name changes, presence of a foreign manager or a manager with domestic education in the surveyed company. Some aggregate data on non-financial corporations used to calculate derived ratios originated at the Statistical Office of the Slovak Republic. These were total exports, real gross domestic product and total revenue of non-financial corporations. ${ }^{16}$

\begin{tabular}{|c|c|c|c|c|c|}
\hline Variable & $\begin{array}{c}\text { Number of } \\
\text { observations }\end{array}$ & Mean & $\begin{array}{l}\text { Standard } \\
\text { Deviation }\end{array}$ & Minimum & Maximum \\
\hline Return on assets (\%) & 622 & 8.1 & 16.2 & 70.0 & 143.0 \\
\hline Export performance (1000 SKK) & 566 & 168138 & 676695 & 0 & 6457512 \\
\hline Labour productivity (1000 SKK) & 646 & 383.7 & 738.2 & 7.1 & 8198.3 \\
\hline Market share (\%) & 725 & 0.2 & 0.6 & 0.0 & 7.0 \\
\hline Labour costs (\%) & 447 & 13.0 & 12.6 & -20.0 & 72.0 \\
\hline Export share (\%) & 566 & 0.4 & 1.8 & 0.0 & 20.0 \\
\hline Foreign management & 810 & 0.178 & 0.383 & 0.00 & 1.00 \\
\hline Efficiency of company leadership & 810 & 2.433 & 0.518 & 1.00 & 3.00 \\
\hline Professionalism of management & 801 & 2.506 & 0.543 & 1.00 & 3.00 \\
\hline Quality of company management & 810 & 2.422 & 0.516 & 1.00 & 3.00 \\
\hline Orientation on cost reduction & 810 & 2.467 & 0.582 & 1.00 & 3.00 \\
\hline $\begin{array}{l}\text { Corporate relationship with other } \\
\text { companies }\end{array}$ & 801 & 2.719 & 0.450 & 2.00 & 3.00 \\
\hline Quality of domestic suppliers & 783 & 1.954 & 0.478 & 1.00 & 3.00 \\
\hline $\begin{array}{l}\text { Existence of developed consumer } \\
\text { sectors }\end{array}$ & 783 & 2.195 & 0.604 & 1.00 & 3.00 \\
\hline Customer demandingness & 801 & 2.528 & 0.583 & 1.00 & 3.00 \\
\hline Nature of competitive advantage & 747 & 2.060 & 0.647 & 1.00 & 3.00 \\
\hline Exchange rate stability & 810 & 1.978 & 0.615 & 1.00 & 3.00 \\
\hline
\end{tabular}

${ }^{16}$ Statistical Office of the Slovak Republic is also the source for additional firm-level variables used in Total Factor Productivity estimation. See Annex 4 for details. 


\begin{tabular}{l|c|c|c|c|c}
\hline EU membership & 810 & 2.511 & 0.582 & 1.00 & 3.00 \\
\hline Euro adoption in Slovakia & 810 & 2.478 & 0.543 & 1.00 & 3.00 \\
\hline $\begin{array}{l}\text { Quality and availability of } \\
\text { telecommunication infrastructure }\end{array}$ & 810 & 2.367 & 0.547 & 1.00 & 3.00 \\
\hline Energy costs & 810 & 1.789 & 0.641 & 1.00 & 3.00 \\
\hline \hline
\end{tabular}

Source: author's calculations.

The list of all analysed variables including their description and original source is available in Annex 2.

\section{MAIN RESULTS}

Following the methodology described in the section 2, there are four core relationships identified (one for profitability, one for productivity, one for export performance and one for market share). In the next phase the specifications are extended by basic company characteristics and by competitiveness factors in order to verify their impact on the four dependent variables. We assume ex-ante that the econometric analysis proves the top 5 survey-based company-specific, sectoral and macro factors of competitiveness to be significant. All qualitative factors (except energy costs) are expected to have a positive sign. All results presented below are those that have passed the tests relevant for GMM estimation, unless otherwise stated. ${ }^{17}$

\section{PROFITABILITY}

Company profitability is represented by return on assets as a function of its lagged value and market share. ${ }^{18}$ Other specifications considering alternative quantitative explanatory variables ${ }^{19}$ are insignificant or lose significance when adding qualitative variables.

Results of the econometric analysis indicate that differences in basic company characteristics of the top Slovak companies do not explain differences in their profitability. Our preliminary econometric analysis taking into account all factors identified by managers indicates that profitability of top Slovak companies is indeed negatively influenced by perceived negatives

\footnotetext{
${ }^{17}$ Hansen $\mathrm{J}$ test for over-identifying restrictions and Arellano-Bond tests for autocorrelation had to be met and number of groups had to exceed number of instruments.

${ }^{18}$ In case of return on equity and return on revenue, there is no combination of the dependent and quantitative variables that satisfy our condition of a dynamic process, i. e. lagged dependent variables are insignificant. The same is true for all profitability indicators (including return on assets) calculated based on after tax profit. This finding suggests that implementing other than dynamic GMM model could be viable. However, based on high correlation between dependent variables and their lags, we rather rely on the assumption of competitiveness being a dynamic process throughout this paper.

${ }^{19}$ See Annex 2 for the list of all variables.
} 
of higher costs of energy and positively influenced by perceived benefits from the European Union membership. ${ }^{20}$

However, a gradual quantitative analysis of profitability determinants reveals more significant macro, sectoral and company-level factors (Table 3, column 1 and Annex 1, table A). In general, they explain higher share of profitability than the lagged dependent variable. At the same time, size of the company's market share remains the key driver of company's profitability.

At the macro level companies' profitability is determined not only by perceived benefits of EU membership and perceived negatives of higher costs of energy, but also by perception of exchange rate stability. Size of the impact of these factors is very similar. The direction of the impact of the perceived medium and high energy costs is, of course, negative. Its effect seems to be outweighed by combined influence of perceived benefits of EU membership and exchange rate stability. ${ }^{21}$

Taking into account company level factors, positive effect of perceived benefits of utilizing communication technology on profitability turns out to be statistically significant. Despite positive expected impact of a company's preference for price (or cost) reduction strategy on its market share, the results indicate that there might be a negative effect in place with regard to profitability. ${ }^{22}$ However, this factor is significant at only $10 \%$ level and the size of its coefficient is significantly lower than in case of high utilisation of telecommunication technologies.

Analysed sector-specific factors seem to have the least important effect on company profitability. None of the top 5 factors is statistically significant separately or in a combination with other top sectoral factors identified in the survey. When adding a factor representing quality of domestic suppliers, there is an effect of developed consumer sectors identified. The interpretation of the negative sign of the coefficient is rationalised by the fact that most of the Slovak companies operate at low or medium levels of global value chains. This implies relatively low negotiating power over their output price. The dominance of consumers proxied by a higher level of development of consumer sectors may then have negative impact on profitability.

We can conclude that the more detailed gradual analysis confirms that several competitiveness factors play a significant role in company profitability, but macro level factors seem to be predominant.

\footnotetext{
${ }^{20}$ See Annex 3 for estimation results.

${ }^{21}$ However, the positive impact of perceived benefits of exchange rate stability is significant only at a $10 \%$ level.

${ }^{22}$ Lower prices may lead to smaller revenue and consequently lower profitability. At the same time, lower prices may contribute to an increase in market share.
} 


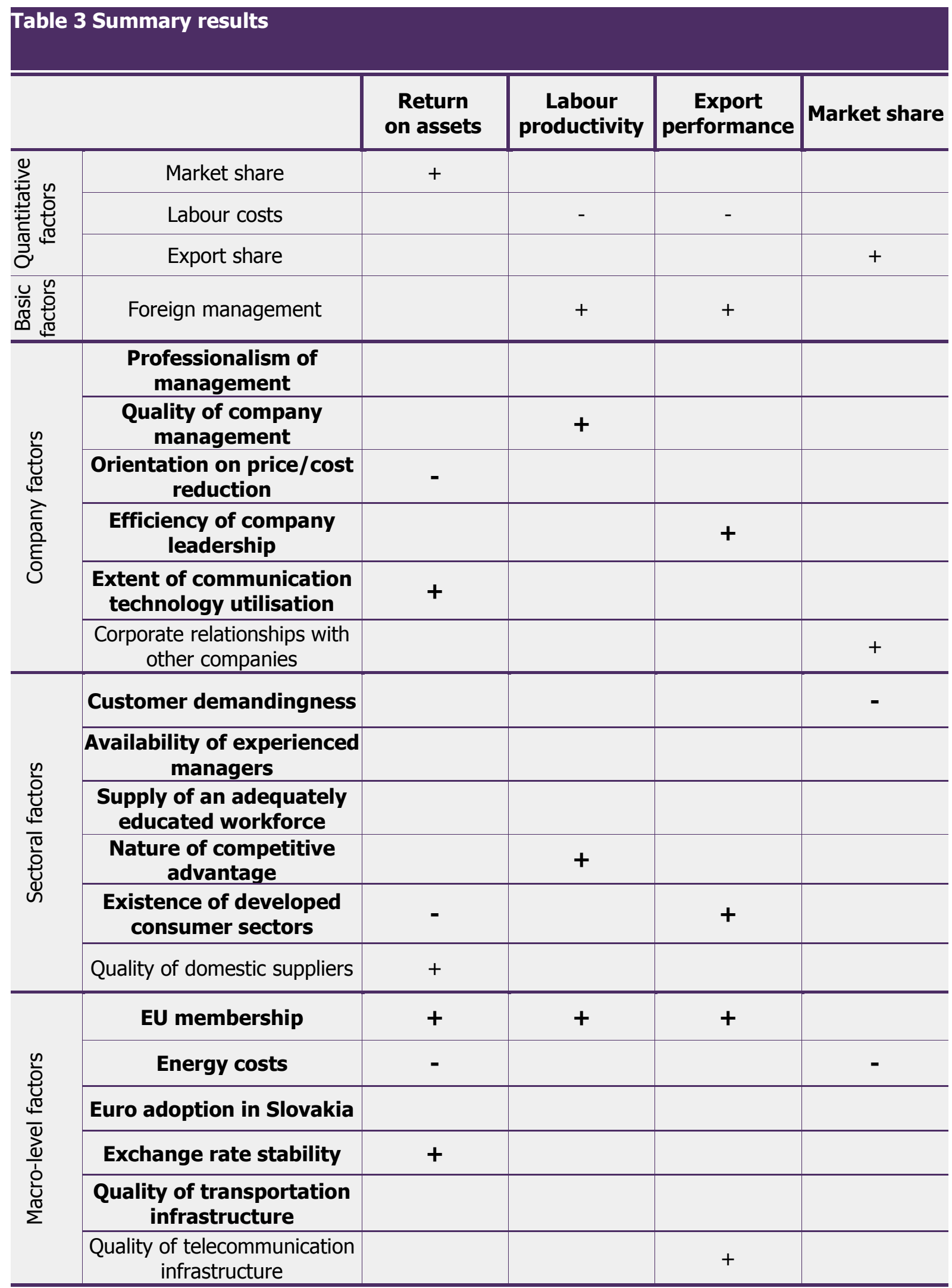

Legend: + statistically significant positive effect; - statistically significant negative effect; top 5 company, sector-specific and macro-level factors identified by the survey in bold. 


\section{LABOUR PRODUCTIVITY}

Labour productivity primarily depends on its lagged value and perceived effect of labour costs, where labour costs are defined as a share of company personal costs on output. ${ }^{23}$ Only labour productivity based on revenue meets the condition of being dependent on its lagged value. ${ }^{24}$ Similarly, as in case of profitability, preliminary models covering all top factors are found not be robust. ${ }^{25}$

A gradual quantitative analysis reveals some statistically significant macro, sectoral and company-level factors (Table 3, column 2 and Annex 1, table B) that do not violate the condition of a dynamic process. Taking into account the effect of basic company characteristics obtained or derived from the Business Register of the Slovak Republic, there is a positive statistically significant impact of foreign management identified in combination with selected company-specific, sectoral and also macro factors. Presence of a foreign manager in a company increases the company's productivity to the approximately same extent as the effect of surveyed factors in general. However, their influence seems to be much smaller than the impact of labour costs or the original level of productivity.

At the macro level corporate productivity is determined by the country EU membership. ${ }^{26}$ At the sector-specific level there is a positive effect of competitive advantage based on efficiency identified.

The gradual econometric analysis does not confirm positive statistically significant direct impact of professional management or efficient leadership on company productivity. At the same time both medium and high quality company management seem to have positive impact on the productivity. But the results of the model should be interpreted with a certain caution. The reported $\mathrm{p}$-value of 0.04 indicates a problem with over-identifying restrictions at a $5 \%$ significance level.

The detailed gradual analysis confirms that labour productivity is primarily dependent on the level of company's labour costs and the value of productivity in the previous period. Some qualitative basic and competitiveness factors seem to contribute to shaping company productivity. But the identified statistically significant foreign management, quality of company management, competitive advantage based on efficiency and EU membership seem to have notably lower impact.

\footnotetext{
${ }^{23}$ In the literature, higher labour costs per employee are frequently associated with higher company competitiveness taking into account the fact that higher labour costs represent higher labour force quality. However, our definition of labour costs corresponds more to a division between labour and capital inputs. In this sense, higher labour costs indicate lower technology intensity, that is crucial for competitiveness of non-financial corporations.

24 Productivity indicators calculated based on value added or value added taking into account amortisation does not behave as a dynamic process. The same is true for total factor productivity, see Annex 4 for estimation results.

25 The lagged dependent variable loses its significance after adding the top 5 company level competitiveness factors to the core model, see Annex 3 for estimation results.

${ }^{26}$ Probability of Hansen test for over-identifying restrictions is relatively low, which cast some doubts on suitability of instruments used in the model.
} 


\section{EXPORT PERFORMANCE}

Export performance represented by value of company's export is modelled as a function of its lagged value and labour costs. Other specifications based on export share on revenue or share of company's export on total export are not statistically significant in relation with labour costs or alternative quantitative explanatory variables.

A gradual analysis shows a statistically significant impact of foreign management on competitiveness. $^{27}$ However, foreign management loses its power when other qualitative competitiveness factors are considered (Table 3, column 3 and Annex 1, table C). Our analysis reveals several company-specific, macro, and to a certain extent also sector-specific factors. In general, absolute value of their coefficients is substantially lower than value for the lagged dependent variable. Perceived impact of labour costs remains the key driver of company's competitiveness measured by export performance. This relationship is even stronger than in the case of labour productivity.

At the macro level Slovak companies' export performance is positively influenced by perceived benefits of EU membership. We can see also a relatively small, but statistically significant impact of perceived benefits of availability of telecommunication infrastructure together with a highly efficient company leadership on export performance. None of the company factors is significant individually or in a combination with other top 15 competitiveness factors. At the sector-specific level we can see developed consumer sectors do have some impact on export. This however may not be fully confirmed due to technical limitations in testing the model.

In terms of export competitiveness, we can conclude that there is a relatively small, but statistically significant impact of foreign management, efficient leadership and euro adoption on competitiveness.

\section{MARKET SHARE}

The analysis of market share determinants is based on a company's share on the total revenue of Slovak non-financial corporations. A company's market share is relatively stable, driven mostly by its lagged value and by the company's export share. ${ }^{28}$ Differences in basic company characteristics do not seem to play a role in market share development of the large Slovak companies.

At the company level, competitiveness measured by market share is not determined by any of the top 5 company factors, but it is positively influenced by additional company factor corporate relationships with other companies. Strong corporate relations are believed to

\footnotetext{
${ }^{27}$ As revealed in case of profitability or productivity analyses, the impact of top 15 factors was not jointly significant. A certain sign of possible statistically significant impact can be seen in case of two company factors (professional management and price/ cost reduction) and one sectoral factor (availability of qualified managers).

${ }^{28}$ In case of market share calculated using value added or value added adjusted by amortisation, there is no combination of the dependent and quantitative independent variables that satisfies our condition of a dynamic process, i. e. lagged dependent variables are insignificant.
} 
contribute to higher market share (similarly than to company's export share). At the same time strong corporate relations are perceived to outweigh negative impact of medium and high energy costs. Impact of the only statistically significant sector-specific factor - demands by customers - is negative, but relatively small.

Our econometric analysis confirms that at least one sector-specific and one macro level factor play a relatively small but statistically significant role in company competitiveness. However, a detailed interpretation should be taken with caution as the results of the test for over-identifying restrictions, or validity of instruments are not fully convincing.

\section{CONCLUSION}

The main goal of the paper is to empirically verify and possibly quantify an impact of company characteristics and factors of perceived company competitiveness. However, the implemented dynamic panel data approach using annual data between 2001 and 2009 of the largest Slovak companies by revenue does not bring unambiguous results. Heterogeneity in the results confirms the core issue that we have attempted to solve in the beginning by differentiated definition of competitiveness. It seems to matter a lot, whether one thinks of a company's competitiveness more in terms of profitability, or in terms of market share, export or productivity. Results of regression analysis based on general method of moments estimator show that the four main competitiveness indicators are driven by different quantitative and qualitative factors. This finding seems to reflect reality. For example, high export performance does not necessarily bring high profitability (and vice versa). Moreover, a goal of high profitability may naturally be achieved by different measures that high export performance.

Profitability of top Slovak companies represented by return on assets seems to be primarily dependent on their local market share. A more detailed gradual analysis confirms that several competitiveness factors play a significant role in company profitability, while macro level factors seem to be predominant. The analysed companies' profitability appears to be negatively affected by perceived medium and high energy costs, but their impact is outweighed by perceived benefits of EU membership and exchange rate stability. Statistically significant factors at the sector-specific level include higher quality of domestic suppliers that contribute positively to higher profitability and developed consumer sectors that contribute negatively. At the company level, profitability seems to be influenced mainly by perception of benefits from the use of communication technology.

Labour productivity and export performance are primarily dependent on the level of company's labour costs and their past performance. In contrast to profitability, competitiveness expressed by these two indicators seems to be influenced not only by specific survey based competitiveness factors, but also by company characteristics per se, e.g. presence of foreign management in the company. However, the identified statistically significant i) foreign management, quality of company management and efficient leadership at the company level; ii) competitive advantage based on efficiency and developed consumer sectors at the sectoral level; and iii) EU membership and euro adoption at the macro level; have notably lower impact than the lagged dependent variable or labour costs. 
Our analysis of company market shares confirms that a push from customer demands and shifts in energy costs play a relatively small, but statistically significant role in company competitiveness. However, a detailed interpretation of factors shaping company market share should be taken with caution since the test results for validity of instruments are not as convincing as in other three specifications.

Returning to the main goal of the analysis, it can be concluded that the regression analysis confirmed that most of the top 15 competitiveness factors identified by a survey among the largest Slovak companies by revenue are statistically significant. We find that presence of foreign management weighs positively on productivity and export performance based competitiveness indicators. We also find that perceived competitiveness factors in general explain relatively large part of the company profitability. The most significant factors overall include the two macro factors - energy costs and EU membership and one sectoral factor developed consumer sectors.

Although this study is based on a relatively small sample of top Slovak companies preventing a more detailed cross-sector comparison, it provides a unique chance to reflect how surveyed perception of managers transmits into measurable indicators of competitiveness.

An additional implication of the analysis is that setting up a questionnaire related to competitiveness requires asking respondents on the quantitative interpretation of competitiveness in the first place. Otherwise, quantitative assessment may become a complex issue. In addition, the results suggest that policies supporting competitiveness should be drawn from clear aims. Improvement in competitiveness indicators measured as productivity, export performance or profitability may require diverse approaches.

\section{REFERENCES}

Andersson et al. (2007): Firm performance and international trade - evidence from a small open economy, Electronic Working Paper Series, Paper No. 99, CESIS.

Anos-Casero and Udomsaph (2009): What drives productivity growth, Policy research working paper 4841, World Bank.

Arellano and Bond (1991): Some tests of specification for panel data: Monte Carlo evidence and an application to employment equations. The Review of Economic Studies, vol. 58, pp. 277-297.

Baltagi (2005): Econometric analysis of panel data, John Wiley \& Sons.

Blundell and Bond (1998): Initial conditions and moment restrictions in dynamic panel data models, Journal of Econometrics, No. 87, pp. 115-143.

Capon (1990): Determinants of Financial Performance: A Meta-Analysis, Management Science, vol. 36, No. 10, pp. 1143-1159.

Dabla-Norris et al. (2010): Firm productivity, innovation, and financial development, IMF Working Paper 10/49, IMF. 
Erste Group (2010): Special report - Operating efficiency of corporate sector in CEE, November 2010.

Feldkircher et al. (2010): Measuring competition in CESEE: Stylized facts and determinants across countries and sectors, Focus on European Economic Integration Q3/10, pp. 38-62, OeNB.

Lalinsky (2008): Competitiveness factors of Slovak companies, Working paper, No. 3, National bank of Slovakia.

Levinsohn and Petrin (2003): Estimating production functions using inputs to control for unobservables, Review of Economic Studies, vol. 70, pp.317-342.

Navaretti et al. (2011): The global operations of European firms: the second EFIGE policy report, BRUEGEL BLUEPRINT SERIES, Volume XII, Breugel.

Nazar and Saleem (2009): Firm-level determinants of export performance, International Business \& Economics Research Journal, vol.8 (2), pp. 105-112.

Nwachukwu and Oseghale (2010): Determinants of small business performance: A metaanalysis, Economics \& Business Journal: Inquiries \& Perspectives, vol. 3 (1), pp. 65-76.

Ospina and Schiffbauer (2010): Competition and firm productivity: Evidence from firm-level data, IMF Working Paper 10/67, IMF.

Petrin, Poi and Levinsohn (2004): Production function estimation in Stata using inputs to control for unobservables, Stata Journal, StataCorp LP, vol. 4(2), pp. 113-123.

Roodman (2006): How to Do xtabond2: An Introduction to "Difference" and "System" GMM in Stata, Working Paper 103, Center for Global Development.

Rutkowski (2006): Inward FDI, concentration, and profitability in the CEECs: Where the domestic firms crowded out or strengthened?, Transnational corporations, vol. 15, No. 3, pp. 105-140.

Sabarwal and Terrell (2008): Does gender matter for firm performance? Evidence from Eastern Europe and Central Asia, Policy Research Working Paper 4705, World Bank.

Sargent and Rodriguez (2001): Labour or total factor productivity: Do we need to choose?, Working Paper 2001-04, Department of Finance Canada.

Serrasqueiro (2009): Growth and profitability in Portuguese companies: a dynamic panel data approach, Economic Interferences, vol. 11(26), pp. 565-573.

Sevestre and Trognon (1985): A note on autoregressive error components models, Journal of Econometrics, Elsevier, vol. 28(2), pp. 231-245.

Stojcic et al. (2011): Innovation activities and competitiveness: Empirical evidence on the behaviour of firms in new EU member states and candidate countries. CASE Network Studies \& Analyses, No. 424, Center for Social and Economic Research.

Syverson (2010): What determines productivity?, Working Paper 15712, NBER.

Zou and Stan (1998): The determinants of export performance: a review of the empirical literature between 1987 and 1997, International Marketing Review, vol. 15 (5), pp.333-356.

Windmeijer (2005): A finite sample correction for the variance of linear efficient two-step GMM estimators, Journal of Econometrics, No. 126, pp. 25-51. 


\section{AnNeX 1 MaIn Results}

\begin{tabular}{|c|c|c|c|c|c|}
\hline & & & Model 1 & Model 2 & Model 3 \\
\hline & & & $\begin{array}{c}\text { return } \\
\text { on assets }\end{array}$ & $\begin{array}{c}\text { return } \\
\text { on assets }\end{array}$ & $\begin{array}{c}\text { return } \\
\text { on assets }\end{array}$ \\
\hline & \multirow{2}{*}{ return on assets $(-1)$} & coef. & $0.215^{\star}$ & $0.236^{*}$ & $0.227^{\star}$ \\
\hline & & s.e. & 0.077 & 0.071 & 0.070 \\
\hline & \multirow{2}{*}{ market share } & coef. & $1.336^{\star \star \star}$ & $1.387^{\star \star}$ & $1.294^{\star \star \star}$ \\
\hline & & s.e. & 0.006 & 0.011 & 0.0096 \\
\hline \multirow{6}{*}{ 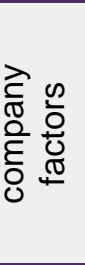 } & \multirow{2}{*}{$\begin{array}{l}\text { company technology } \\
\text { utilisation (high) }\end{array}$} & coef. & $0.303^{\star \star}$ & & \\
\hline & & s.e. & 0.016 & & \\
\hline & \multirow{2}{*}{$\begin{array}{l}\text { price/cost reduction } \\
\text { (medium) }\end{array}$} & coef. & $-0.183^{\star}$ & & \\
\hline & & s.e. & 0.050 & & \\
\hline & \multirow{2}{*}{ price/cost reduction (high) } & coef. & -0.1304 & & \\
\hline & & s.e. & 0.211 & & \\
\hline \multirow{8}{*}{ 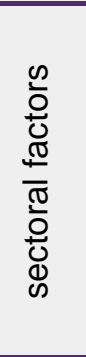 } & \multirow{2}{*}{$\begin{array}{l}\text { quality domestic suppliers } \\
\text { (medium) }\end{array}$} & coef. & & $0.426^{* \star}$ & \\
\hline & & s.e. & & 0.014 & \\
\hline & \multirow{2}{*}{$\begin{array}{l}\text { quality domestic. suppliers } \\
\text { (high) }\end{array}$} & coef. & & 0.0277 & \\
\hline & & s.e. & & 0.900 & \\
\hline & \multirow{2}{*}{$\begin{array}{l}\begin{array}{l}\text { developed consumers } \\
\text { (medium) }\end{array} \\
\end{array}$} & coef. & & $-0.362^{\star \star}$ & \\
\hline & & s.e. & & 0.023 & \\
\hline & \multirow{2}{*}{ developed consumers (high) } & coef. & & -0.255 & \\
\hline & & s.e. & & 0.155 & \\
\hline \multirow{21}{*}{ 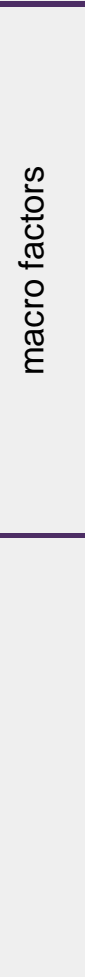 } & \multirow{2}{*}{ energy costs (medium) } & coef. & & & $-0.453^{\star \star \star}$ \\
\hline & & s.e. & & & 0.001 \\
\hline & \multirow{2}{*}{ energy costs (high) } & coef. & & & $-0.393^{\star \star}$ \\
\hline & & s.e. & & & 0.014 \\
\hline & \multirow{2}{*}{$\begin{array}{l}\text { exchange rate stability } \\
\text { (medium) }\end{array}$} & coef. & & & 0.0632 \\
\hline & & s.e. & & & 0.533 \\
\hline & \multirow{2}{*}{$\begin{array}{l}\text { exchange rate stability } \\
\text { (high) }\end{array}$} & coef. & & & $0.356^{\star}$ \\
\hline & & s.e. & & & 0.066 \\
\hline & \multirow{2}{*}{ EU membership (medium) } & coef. & & & $0.388^{\star \star}$ \\
\hline & & s.e. & & & 0.013 \\
\hline & \multirow{2}{*}{ EU membership (high) } & coef. & & & $0.388^{\star \star \star}$ \\
\hline & & s.e. & & & 0.008 \\
\hline & \multicolumn{2}{|l|}{ Number of observations } & 529 & 502 & 532 \\
\hline & \multicolumn{2}{|l|}{ Number of groups } & 75 & 72 & 75 \\
\hline & \multicolumn{2}{|l|}{ Number of instruments } & 28 & 29 & 31 \\
\hline & \multicolumn{2}{|l|}{ Arellano-Bond test for AR(1) } & -1.880 & -1.853 & -1.906 \\
\hline & \multicolumn{2}{|l|}{ Prob (Arellano-Bond test for AR(1)) } & 0.060 & 0.064 & 0.057 \\
\hline & \multicolumn{2}{|l|}{ Arellano-Bond test for AR(2) } & 1.214 & 1.247 & 1.207 \\
\hline & \multicolumn{2}{|c|}{ Prob (Arellano-Bond test for AR(2)) } & 0.225 & 0.213 & 0.227 \\
\hline & \multicolumn{2}{|l|}{ Hansen test for over-id. restrictions } & 29.232 & 27.742 & 28.798 \\
\hline & Prob (Hansen test for over-id. re & str.) & 0.173 & 0.226 & 0.187 \\
\hline
\end{tabular}




\begin{tabular}{|c|c|c|c|c|c|}
\hline & & & \multirow{2}{*}{$\begin{array}{c}\text { Model } 1 \\
\text { labour } \\
\text { productivity } \\
\end{array}$} & \multirow{2}{*}{$\begin{array}{c}\text { Model } 2 \\
\text { labour } \\
\text { productivity }\end{array}$} & \multirow{2}{*}{$\begin{array}{c}\text { Model } 3 \\
\begin{array}{c}\text { labour } \\
\text { productivity }\end{array}\end{array}$} \\
\hline & & & & & \\
\hline & \multirow{2}{*}{ labour productivity $(-1)$} & coef. & $0.313^{\star}$ & $0.462^{\star \star \star}$ & $0.338^{*}$ \\
\hline & & s.e. & 0.067 & 0.004 & 0.067 \\
\hline & \multirow{2}{*}{ labour costs } & coef. & $-0.888^{\star \star \star}$ & $-0.868^{\star \star \star}$ & $-0.867^{\star \star \star}$ \\
\hline & & s.e. & 0.000 & 0.0000 & 0.000 \\
\hline \multirow{2}{*}{$\begin{array}{l}\text { basic } \\
\text { factor }\end{array}$} & \multirow{2}{*}{ foreign management } & coef. & $0.0285^{\star \star}$ & $0.033^{\star}$ & $0.039^{\star \star \star}$ \\
\hline & & s.e. & 0.019 & 0.064 & 0.009 \\
\hline \multirow{4}{*}{ 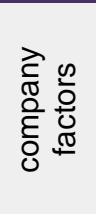 } & \multirow{2}{*}{$\begin{array}{l}\text { quality of management } \\
\text { (medium) }\end{array}$} & coef. & $0.038^{\star \star}$ & & \\
\hline & & s.e. & 0.020 & & \\
\hline & \multirow{2}{*}{$\begin{array}{l}\text { quality of management } \\
\text { (high) }\end{array}$} & coef. & $0.032^{*}$ & & \\
\hline & & s.e. & 0.073 & & \\
\hline \multirow{4}{*}{ 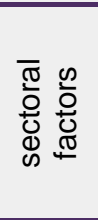 } & \multirow{2}{*}{$\begin{array}{l}\text { nature of competitive } \\
\text { advantage (medium) }\end{array}$} & coef. & & $0.028^{*}$ & \\
\hline & & s.e. & & 0.079 & \\
\hline & \multirow{2}{*}{$\begin{array}{l}\text { nature of competitive } \\
\text { advantage (high) }\end{array}$} & coef. & & 0.020 & \\
\hline & & s.e. & & 0.348 & \\
\hline \multirow{13}{*}{ 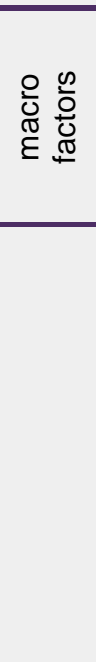 } & \multirow{2}{*}{ EU membership (medium) } & coef. & & & $0.039^{\star \star \star}$ \\
\hline & & s.e. & & & 0.005 \\
\hline & \multirow{2}{*}{ EU membership (high) } & coef. & & & 0.024 \\
\hline & & s.e. & & & 0.293 \\
\hline & \multicolumn{2}{|l|}{ Number of observations } & 290 & 260 & 273 \\
\hline & \multicolumn{2}{|l|}{ Number of groups } & 76 & 69 & 72 \\
\hline & \multicolumn{2}{|l|}{ Number of instruments } & 14 & 14 & 16 \\
\hline & \multicolumn{2}{|l|}{ Arellano-Bond test for $\mathrm{AR}(1)$} & -1.176 & -1.077 & -1.147 \\
\hline & \multicolumn{2}{|c|}{ Prob (Arellano-Bond test for AR(1)) } & 0.240 & 0.281 & 0.251 \\
\hline & \multicolumn{2}{|l|}{ Arellano-Bond test for AR(2) } & 0.619 & 0.571 & 0.592 \\
\hline & \multicolumn{2}{|c|}{ Prob (Arellano-Bond test for AR(2)) } & 0.536 & 0.568 & 0.554 \\
\hline & \multicolumn{2}{|c|}{ Hansen test for over-id. restrictions } & 17.531 & 10.843 & 17.454 \\
\hline & \multicolumn{2}{|c|}{ Prob (Hansen test for over-id. restr.) } & 0.041 & 0.287 & 0.095 \\
\hline
\end{tabular}

legend: * $p<.1 ;{ }^{* *} p<.05 ;{ }^{* *} p<.01$

Note: Dependent variables, lagged dependent variables and quantitative explanatory variables in logarithm. Dummy variables for competitiveness factors. Two-step difference GMM estimation using xtabond 2 module for Stata. Asymptotic robust standard errors are reported. Lagged dependent and differenced explanatory variables used as instruments. 


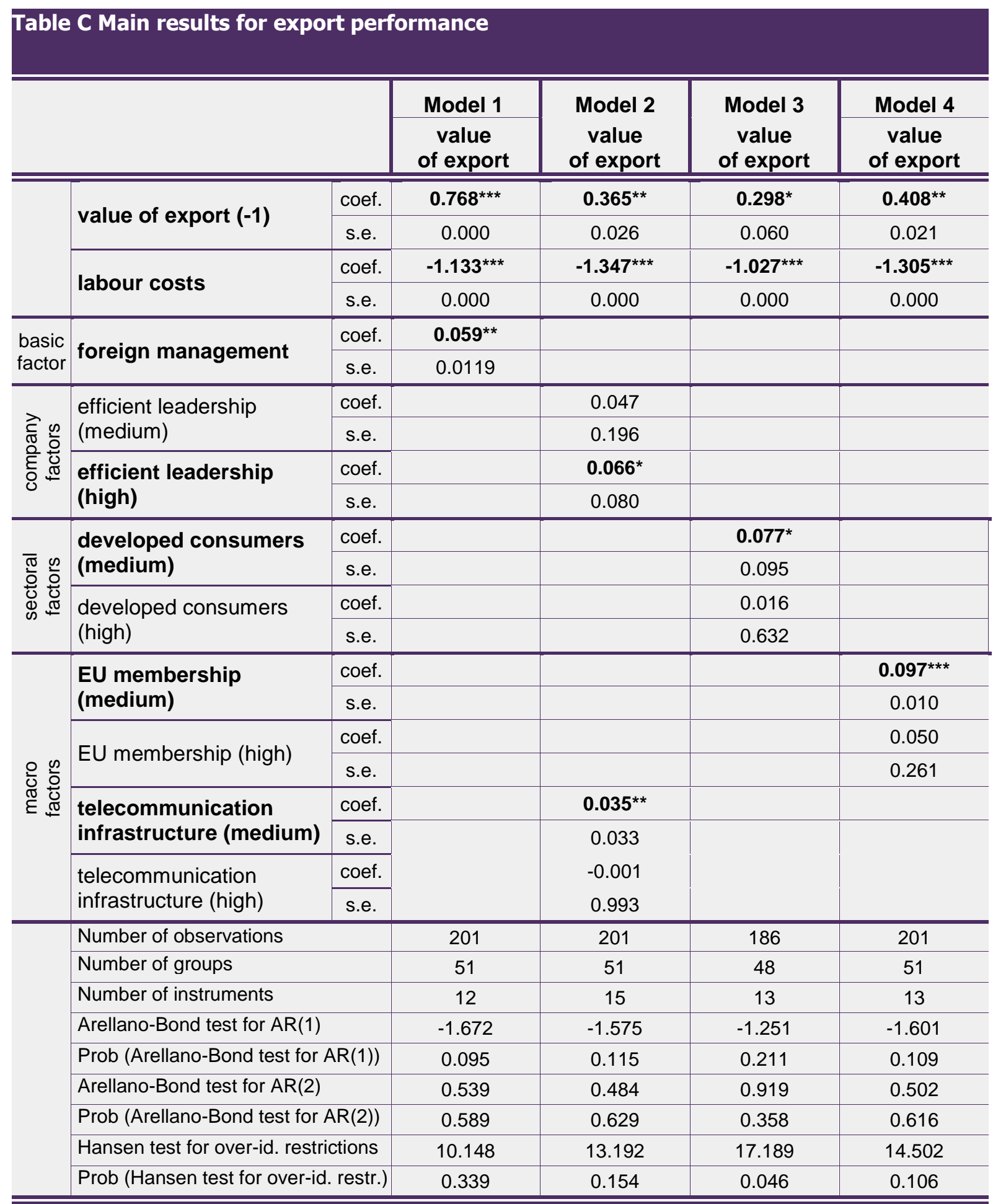

legend: * $p<.1 ;{ }^{* *} p<.05 ;{ }^{* * *} p<.01$

Note: Dependent variables, lagged dependent variables and quantitative explanatory variables in logarithm. Dummy variables for competitiveness factors. Two-step difference GMM estimation using xtabond2 module for Stata. Asymptotic robust standard errors are reported. Lagged dependent and differenced explanatory variables used as instruments. 


\begin{tabular}{|c|c|c|c|c|c|}
\hline & & & Model 1 & Model 2 & Model 3 \\
\hline & & & $\begin{array}{l}\text { market } \\
\text { share }\end{array}$ & $\begin{array}{l}\text { market } \\
\text { share }\end{array}$ & $\begin{array}{c}\text { market } \\
\text { share }\end{array}$ \\
\hline & \multirow{2}{*}{ market share (-1) } & coef. & $0.252^{\star \star \star}$ & $0.329^{\star *}$ & $0.262^{\star \star \star}$ \\
\hline & & s.e. & 0.002 & 0.037 & 0.002 \\
\hline & \multirow{2}{*}{ export share } & coef. & $0.148^{\star \star}$ & $0.133^{*}$ & $0.156^{\star \star}$ \\
\hline & & s.e. & 0.025 & 0.065 & 0.025 \\
\hline \multirow{4}{*}{ 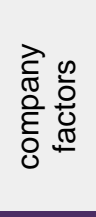 } & \multirow{2}{*}{ corporate relations (medium) } & coef. & 0.002 & & \\
\hline & & s.e. & 0.924 & & \\
\hline & \multirow{2}{*}{ corporate relations (high) } & coef. & $0.090^{\star *}$ & & \\
\hline & & s.e. & 0.011 & & \\
\hline \multirow{4}{*}{ 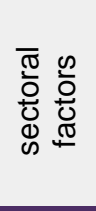 } & \multirow{2}{*}{$\begin{array}{l}\text { customer demandingness } \\
\text { (medium) }\end{array}$} & coef. & & $-0.043^{\star \star \star}$ & \\
\hline & & s.e. & & 0.001 & \\
\hline & \multirow{2}{*}{$\begin{array}{l}\text { customer demandingness } \\
\text { (high) }\end{array}$} & coef. & & $-0.033^{\star \star}$ & \\
\hline & & s.e. & & 0.022 & \\
\hline \multirow{4}{*}{ 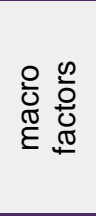 } & \multirow{2}{*}{ energy costs (medium) } & coef. & $-0.024^{\star}$ & & $-0.022^{\star}$ \\
\hline & & s.e. & 0.064 & & 0.079 \\
\hline & \multirow{2}{*}{ energy costs (high) } & coef. & $-0.058^{\star \star \star}$ & & $-0.040^{\star *}$ \\
\hline & & s.e. & 0.008 & & 0.019 \\
\hline & \multicolumn{2}{|l|}{ Number of observations } & 452 & 397 & 470 \\
\hline & \multicolumn{2}{|l|}{ Number of groups } & 64 & 64 & 66 \\
\hline & \multicolumn{2}{|l|}{ Number of instruments } & 26 & 21 & 24 \\
\hline & \multicolumn{2}{|l|}{ Arellano-Bond test for $\mathrm{AR}(1)$} & -0.502 & -1.026 & -0.976 \\
\hline & \multicolumn{2}{|l|}{ Prob (Arellano-Bond test for AR(1)) } & 0.616 & 0.305 & 0.329 \\
\hline & \multicolumn{2}{|l|}{ Arellano-Bond test for AR(2) } & 1.101 & 2.028 & 1.408 \\
\hline & \multicolumn{2}{|l|}{ Prob (Arellano-Bond test for AR(2)) } & 0.271 & 0.043 & 0.159 \\
\hline & \multicolumn{2}{|l|}{ Hansen test for over-id. restrictions } & 29.382 & 25.697 & 31.202 \\
\hline & \multicolumn{2}{|c|}{ Prob (Hansen test for over-id. restr.) } & 0.081 & 0.080 & 0.053 \\
\hline
\end{tabular}

legend: * $p<.1 ;{ }^{* *} p<.05 ;{ }^{* * *} p<.01$

Note: Dependent variables, lagged dependent variables and quantitative explanatory variables in logarithm. Dummy variables for competitiveness factors. Two-step difference GMM estimation using xtabond2 module for Stata. Asymptotic robust standard errors are reported. Lagged dependent and differenced explanatory variables used as instruments. 


\section{ANNEX 2 LIST OF VARIABLES}

\begin{tabular}{|c|c|c|}
\hline Variable & Description & $\begin{array}{l}\text { Original } \\
\text { source }\end{array}$ \\
\hline Return on assets & gross (net) company profit / total company assets & $\begin{array}{l}\text { TREND } \\
\text { Analyses }\end{array}$ \\
\hline Return on equity & gross (net) company profit / total company equity & $\begin{array}{l}\text { TREND } \\
\text { Analyses }\end{array}$ \\
\hline Profit margin & gross (net) company profit / total company revenue & $\begin{array}{l}\text { TREND } \\
\text { Analyses }\end{array}$ \\
\hline Export performance & total nominal company export & $\begin{array}{l}\text { TREND } \\
\text { Analyses }\end{array}$ \\
\hline Labour productivity & total company revenue / number of employees & $\begin{array}{l}\text { TREND } \\
\text { Analyses }\end{array}$ \\
\hline $\begin{array}{l}\text { Labour productivity based on value } \\
\text { added }\end{array}$ & total company value added / number of employees & $\begin{array}{l}\text { TREND } \\
\text { Analyses }\end{array}$ \\
\hline Capital productivity & total company capital / number of employees & $\begin{array}{c}\text { TREND } \\
\text { Analyses }\end{array}$ \\
\hline Market share & $\begin{array}{l}\text { total company revenue / total revenue of non-financial } \\
\text { companies in Slovakia }\end{array}$ & $\begin{array}{l}\text { TREND } \\
\text { Analyses }\end{array}$ \\
\hline Export share & $\begin{array}{l}\text { total company export / total export of non-financial } \\
\text { companies in Slovakia }\end{array}$ & $\begin{array}{l}\text { TREND } \\
\text { Analyses }\end{array}$ \\
\hline Value added adjusted for amortisation & company value added - amortisation & $\begin{array}{c}\text { TREND } \\
\text { Analyses }\end{array}$ \\
\hline Value added & company value added & $\begin{array}{l}\text { TREND } \\
\text { Analyses }\end{array}$ \\
\hline Labour costs & company personal costs / revenue & $\begin{array}{l}\text { TREND } \\
\text { Analyses }\end{array}$ \\
\hline Revenue performance & total company revenue & $\begin{array}{c}\text { TREND } \\
\text { Analyses }\end{array}$ \\
\hline Investment activity & total company investments & $\begin{array}{l}\text { TREND } \\
\text { Analyses }\end{array}$ \\
\hline Investment intensity & total company investments / total company revenue & $\begin{array}{l}\text { TREND } \\
\text { Analyses }\end{array}$ \\
\hline Investment productivity & $\begin{array}{l}\text { total company revenue / (long-term assets - long-term } \\
\text { assets }(-1))\end{array}$ & $\begin{array}{l}\text { TREND } \\
\text { Analyses }\end{array}$ \\
\hline Company capital & company long-term assets & $\begin{array}{l}\text { TREND } \\
\text { Analyses }\end{array}$ \\
\hline Share of foreign capital & foreign capital / total company capital & $\begin{array}{l}\text { TREND } \\
\text { Analyses }\end{array}$ \\
\hline Capital intensity & company long-term assets / total company revenue & $\begin{array}{l}\text { TREND } \\
\text { Analyses }\end{array}$ \\
\hline Fixed assets & company fixed assets & $\begin{array}{l}\text { TREND } \\
\text { Analyses }\end{array}$ \\
\hline Amortisation & company amortisation & $\begin{array}{l}\text { TREND } \\
\text { Analyses }\end{array}$ \\
\hline Number of employees & average number of company employees & $\begin{array}{l}\text { TREND } \\
\text { Analyses }\end{array}$ \\
\hline Personal costs & company personal costs & $\begin{array}{c}\text { TREND } \\
\text { Analyses }\end{array}$ \\
\hline Loans & company loans & $\begin{array}{l}\text { TREND } \\
\text { Analyses }\end{array}$ \\
\hline Leverage & company loans / company assets & $\begin{array}{l}\text { TREND } \\
\text { Analyses }\end{array}$ \\
\hline
\end{tabular}




\begin{tabular}{|c|c|c|}
\hline Company age & number of months since establishment & $\begin{array}{l}\text { TREND } \\
\text { Analyses }\end{array}$ \\
\hline Industrial company & binary dummy variable for industrial company & $\begin{array}{l}\text { TREND } \\
\text { Analyses }\end{array}$ \\
\hline Network company & $\begin{array}{l}\text { binary dummy variable for company from network } \\
\text { industry sector }\end{array}$ & $\begin{array}{l}\text { TREND } \\
\text { Analyses }\end{array}$ \\
\hline Accounting year & $\begin{array}{c}\text { binary dummy variable for company using other than } \\
\text { standard calendar year }\end{array}$ & $\begin{array}{l}\text { TREND } \\
\text { Analyses }\end{array}$ \\
\hline Export from Slovakia & Total export from Slovakia & $\begin{array}{c}\begin{array}{c}\text { Statistical office } \\
\text { of SR }\end{array} \\
\end{array}$ \\
\hline GDP in Slovakia & Current value of gross domestic product & $\begin{array}{l}\text { Statistical office } \\
\text { of SR }\end{array}$ \\
\hline Foreign management & $\begin{array}{l}\text { binary dummy variable for company employing a } \\
\text { manager with a foreign name }\end{array}$ & $\begin{array}{l}\text { Business } \\
\text { register }\end{array}$ \\
\hline Management with domestic education & $\begin{array}{c}\text { binary dummy variable for company employing a } \\
\text { manager with Slovak title, 'Ing.' 'Mgr.', etc. }\end{array}$ & $\begin{array}{l}\text { Business } \\
\text { register }\end{array}$ \\
\hline Name change & $\begin{array}{l}\text { binary dummy variable for company that has changed } \\
\text { its name since its establishment }\end{array}$ & $\begin{array}{l}\text { Business } \\
\text { register }\end{array}$ \\
\hline Effieciency of company leadership & $\begin{array}{c}\text { separate binary dummy variable for one of three current } \\
\text { levels of the competitiveness factor }\end{array}$ & Lalinsky (2008) \\
\hline Professionalism of management & $\begin{array}{c}\text { separate binary dummy variable for one of three current } \\
\text { levels of the competitiveness factor }\end{array}$ & Lalinsky (2008) \\
\hline Quality of company management & $\begin{array}{c}\text { separate binary dummy variable for one of three current } \\
\text { levels of the competitiveness factor }\end{array}$ & Lalinsky (2008) \\
\hline Orientation on cost/price reduction & $\begin{array}{c}\text { separate binary dummy variable for one of three current } \\
\text { levels of the competitiveness factor }\end{array}$ & Lalinsky (2008) \\
\hline $\begin{array}{l}\text { Company utilisation of communication } \\
\text { technology }\end{array}$ & $\begin{array}{c}\text { separate binary dummy variable for one of three current } \\
\text { levels of the competitiveness factor }\end{array}$ & Lalinsky (2008) \\
\hline $\begin{array}{l}\text { Corporate relationship with other } \\
\text { companies }\end{array}$ & $\begin{array}{c}\text { separate binary dummy variable for one of three current } \\
\text { levels of the competitiveness factor }\end{array}$ & Lalinsky (2008) \\
\hline Quality of domestic suppliers & $\begin{array}{c}\text { separate binary dummy variable for one of three current } \\
\text { levels of the competitiveness factor }\end{array}$ & Lalinsky (2008) \\
\hline $\begin{array}{l}\text { Existence of developed consumer } \\
\text { sectors }\end{array}$ & $\begin{array}{r}\text { separate binary dumm } \\
\text { levels of the }\end{array}$ & Lalinsky (2008) \\
\hline Customer demandingness & $\begin{array}{c}\text { separate binary dummy variable for one of three current } \\
\text { levels of the competitiveness factor }\end{array}$ & Lalinsky (2008) \\
\hline Nature of competitive advantage & $\begin{array}{c}\text { separate binary dummy variable for one of three current } \\
\text { levels of the competitiveness factor }\end{array}$ & Lalinsky (2008) \\
\hline $\begin{array}{l}\text { Availability of skilled and qualified } \\
\text { managers }\end{array}$ & $\begin{array}{l}\text { separate binary dummy variable for one of three current } \\
\text { levels of the competitiveness factor }\end{array}$ & Lalinsky (2008) \\
\hline $\begin{array}{l}\text { Availability of adequately educated } \\
\text { workforce }\end{array}$ & $\begin{array}{c}\text { separate binary dummy variable for one of three current } \\
\text { levels of the competitiveness factor }\end{array}$ & Lalinsky (2008) \\
\hline Exchange rate stability & $\begin{array}{c}\text { separate binary dummy variable for one of three current } \\
\text { levels of the competitiveness factor }\end{array}$ & Lalinsky (2008) \\
\hline EU membership & $\begin{array}{c}\text { separate binary dummy variable for one of three current } \\
\text { levels of the competitiveness factor }\end{array}$ & Lalinsky (2008) \\
\hline Euro adoption in Slovakia & $\begin{array}{c}\text { separate binary dummy variable for one of three current } \\
\text { levels of the competitiveness factor }\end{array}$ & Lalinsky (2008) \\
\hline $\begin{array}{l}\text { Quality and availability of } \\
\text { telecommunication infrastructure }\end{array}$ & $\begin{array}{c}\text { separate binary dummy variable for one of three current } \\
\text { levels of the competitiveness factor }\end{array}$ & Lalinsky (2008) \\
\hline $\begin{array}{l}\text { Quality and availability of transport } \\
\text { infrastructure }\end{array}$ & $\begin{array}{c}\text { separate binary dummy variable for one of three current } \\
\text { levels of the competitiveness factor }\end{array}$ & Lalinsky (2008) \\
\hline Energy costs & $\begin{array}{c}\text { separate binary dummy variable for one of three current } \\
\text { levels of the competitiveness factor }\end{array}$ & Lalinsky (2008) \\
\hline
\end{tabular}

Note: all variables except dummy variables entered regressions in logs. 
Table A2.1 Preliminary results for profitability

\begin{tabular}{|c|c|c|c|c|c|}
\hline & Model 1 & Model 2 & Model 3 & Model 4 \\
\hline & & return on assets & return on assets & return on assets & return on assets \\
\hline & return on assets $(-1)$ & $.2580991^{\star \star}$ & 20687405 & .25109182 & $.20541169^{*}$ \\
\hline & market share & .11470961 & $1.263662^{\star \star \star}$ & $1.0934529^{*}$ & $1.2677263^{\star \star \star}$ \\
\hline \multirow{9}{*}{ 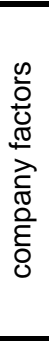 } & efficient leadership (med) & .32666676 & $.4220028^{* * *}$ & & \\
\hline & efficient leadership (high) & $.38014443^{*}$ & .03866954 & & \\
\hline & professional management (med) & -.14684975 & $-1.1361114^{\star * *}$ & & \\
\hline & professional management (high) & -.16049377 & $-1.365659^{* * *}$ & & \\
\hline & quality management (med) & -.01185929 & $.767912^{* * *}$ & & \\
\hline & quality management (high) & -.02095178 & $1.0638106^{\star * \star}$ & & \\
\hline & price/cost reduction (med) & $-.12782072^{\star *}$ & -.11295982 & & \\
\hline & price/cost reduction (high) & $-.10456949^{\star *}$ & .07719797 & & \\
\hline & com. tech. utilisation (high) & $.10415736^{*}$ & $.27997265^{* \star}$ & & \\
\hline \multirow{10}{*}{ 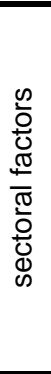 } & developed consumers (med) & .0036666 & & -.16467052 & \\
\hline & developed consumers (high) & -.0560001 & & -.18503466 & \\
\hline & customer demandingness (med) & $-.15226348^{* *}$ & & .32392237 & \\
\hline & customer demandingness (high) & $-.13731837^{\star}$ & & .2921097 & \\
\hline & nature of comp. adv. (med) & .02922501 & & -.01624898 & \\
\hline & nature of comp. adv. (high) & $.06365486^{*}$ & & -.1700415 & \\
\hline & av. of qualified managers (med) & .0298069 & & .11862016 & \\
\hline & av. of qualified managers (high) & -.08319849 & & .18716339 & \\
\hline & adeq. educated workforce (med) & .05889789 & & $-.20733008^{*}$ & \\
\hline & adeq. educated workforce (high) & $.1560339^{\star *}$ & & -.27106649 & \\
\hline \multirow{17}{*}{ 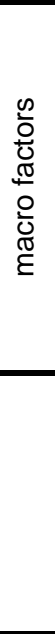 } & exch. rate stability (med) & .05079828 & & & -.00272707 \\
\hline & exch. rate stability (high) & .02302983 & & & .28032062 \\
\hline & EU membership (med) & $-.15398505^{*}$ & & & $.42895546^{\star \star \star}$ \\
\hline & EU membership (high) & $-.17784857^{\star}$ & & & $.43182696^{\star \star}$ \\
\hline & euro adoption (med) & .10971467 & & & .10943767 \\
\hline & euro adoption (high) & .12370127 & & & .03068109 \\
\hline & quality transport infr. (med) & .01546302 & & & .07374627 \\
\hline & quality transport infr. (high) & -.0183894 & & & .20582371 \\
\hline & energy costs (med) & -.0261451 & & & $-.55378598^{\star * \star}$ \\
\hline & energy costs (high) & -.02827431 & & & $-.52892624^{\star *}$ \\
\hline & Number of observations & 555 & 522 & 478 & 532 \\
\hline & Arellano-Bond test for $\mathrm{AR}(1)$ & -1.8712286 & -1.8547095 & -1.7952355 & -1.8808797 \\
\hline & Prob (Arellano-Bond test for $\mathrm{AR}(1))$ & .0613134 & .06363771 & .07261619 & .05998829 \\
\hline & Arellano-Bond test for AR(2) & 1.2014544 & 1.149384 & 1.1511198 & 1.1852189 \\
\hline & Prob (Arellano-Bond test for AR(2)) & .22957497 & .25039766 & .24968295 & .23593089 \\
\hline & Hansen test for over-id. restrictions & 40.607304 & 32.305497 & 29.301833 & 30.193299 \\
\hline & Prob (Hansen test for over-id. restr.) & .27449657 & .09395499 & .17051011 & .14393271 \\
\hline
\end{tabular}

Note: : Dependent variables, lagged dependent variables and quantitative explanatory variables in logarithm. Dummy variables for competitiveness factors. Two-step difference GMM estimation using xtabond2 module for Stata.

Asymptotic robust standard errors are reported. Lagged dependent and differenced explanatory variables used as instruments. 
Table A2.2 Preliminary results for labour productivity

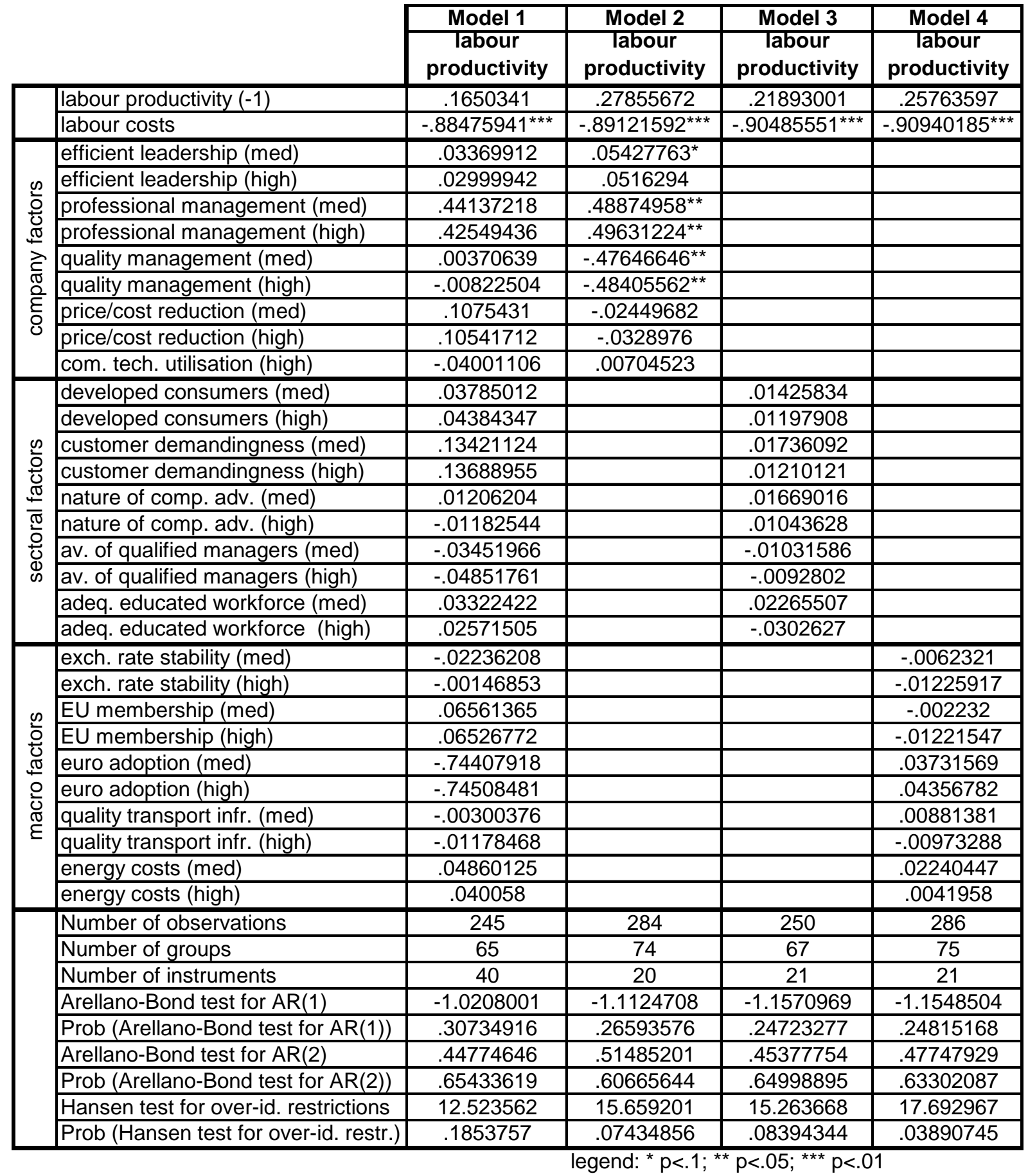

Note: : Dependent variables, lagged dependent variables and quantitative explanatory variables in logarithm. Dummy variables for competitiveness factors. Two-step difference GMM estimation using xtabond2 module for Stata. Asymptotic robust standard errors are reported. Lagged dependent and differenced explanatory variables used as instruments. 
Table A2.3 Preliminary results for export performance

\begin{tabular}{|c|c|c|c|c|c|}
\hline & \multirow{2}{*}{ Model 1} & \multirow{2}{*}{$\begin{array}{l}\text { Model 2 } \\
\text { value of } \\
\text { export }\end{array}$} & \multirow{2}{*}{$\begin{array}{c}\text { Model } 3 \\
\text { value of } \\
\text { export }\end{array}$} & \multirow{2}{*}{$\begin{array}{c}\text { Model } 4 \\
\text { value of } \\
\text { export }\end{array}$} \\
\hline & & & & & \\
\hline & value of export $(-1)$ & .25258781 & .36055511 & .45465306 & $.44203945^{\star \star}$ \\
\hline & labour costs & $-1.2598429^{\star * *}$ & $-1.3327221^{* * *}$ & $-1.0076641^{* * *}$ & $-1.2826774^{* * \star}$ \\
\hline \multirow{9}{*}{ 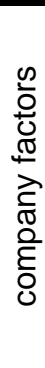 } & efficient leadership (med) & -.01414766 & .03119187 & & \\
\hline & efficient leadership (high) & -.02529739 & -.03319711 & & \\
\hline & professional managemen (med) & .33662173 & $.58596792^{*}$ & & \\
\hline & professional managemen (high) & .40122246 & $.63433476^{*}$ & & \\
\hline & quality management (med) & -.28635852 & -.51477752 & & \\
\hline & quality management (high) & -.25392756 & -.47639438 & & \\
\hline & price/cost reduction (med) & .10093313 & -.0203094 & & \\
\hline & price/cost reduction (high) & -.00073076 & $-.0861969^{*}$ & & \\
\hline & com. tech. utilisation (high) & -.03485794 & .0230002 & & \\
\hline \multirow{10}{*}{ 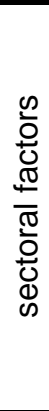 } & developed consumers (med) & -.11751373 & & .079681 & \\
\hline & developed consumers (high) & $\begin{array}{l}-.03934344 \\
\end{array}$ & & $\begin{array}{l}-.03599128 \\
\end{array}$ & \\
\hline & customer demandingness (med) & -.11148906 & & .07343077 & \\
\hline & customer demandingness (high) & -.09133365 & & .03583408 & \\
\hline & nature of comp. adv. (med) & .04052226 & & -.03831693 & \\
\hline & nature of comp. adv. (high) & -.01702067 & & .00049947 & \\
\hline & av. of qualified managers (med) & .07427622 & & -.00495206 & \\
\hline & av. of qualified managers (high) & -.07671149 & & $-.10947616^{*}$ & \\
\hline & adeq. educated workforce (med) & -.06280605 & & -.018501 & \\
\hline & adeq. educated workforce (high) & & & .21539465 & \\
\hline \multirow{19}{*}{ 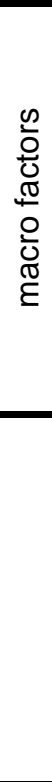 } & exch. rate stability (med) & .04706605 & & & .01010199 \\
\hline & \begin{tabular}{|l} 
exch. rate stability (high) \\
\end{tabular} & .02662971 & & & .00319704 \\
\hline & EU membership (med) & .09144768 & & & .08019256 \\
\hline & EU membership (high) & .01911374 & & & .03276991 \\
\hline & euro adoption (med) & .08159347 & & & .03364084 \\
\hline & euro adoption (high) & & & & -.01038539 \\
\hline & quality transport infr. (med) & .05342346 & & & .05364466 \\
\hline & quality transport infr. (high) & .33402064 & & & .11250256 \\
\hline & energy costs (med) & .02032107 & & & -.006135 \\
\hline & energy costs (high) & -.06046227 & & & -.07445332 \\
\hline & Number of observations & 172 & 200 & 177 & 197 \\
\hline & Number of groups & 44 & 50 & 46 & 50 \\
\hline & Number of instruments & 38 & 20 & 21 & 21 \\
\hline & Arellano-Bond test for $\mathrm{AR}(1)$ & -1.1639132 & -1.4416826 & -1.2046135 & -1.6182664 \\
\hline & Prob (Arellano-Bond test for AR(1)) & .24445917 & .14939193 & .22835256 & .1056052 \\
\hline & Arellano-Bond test for AR(2) & .69550611 & .41502033 & .86548594 & .43800777 \\
\hline & Prob (Arellano-Bond test for AR(2)) & .48673818 & .67812702 & .38677213 & .66138065 \\
\hline & Hansen test for over-id. restrictions & 11.714122 & 13.030365 & 14.276628 & 12.571101 \\
\hline & Prob (Hansen test for over-id. restr.) & .22990967 & .16123711 & .11281967 & .18299292 \\
\hline
\end{tabular}

Note: : Dependent variables, lagged dependent variables and quantitative explanatory variables in logarithm. Dummy variables for competitiveness factors. Two-step difference GMM estimation using xtabond2 module for Stata. Asymptotic robust standard errors are reported. Lagged dependent and differenced explanatory variables used as instruments. 
Table A2.4 Preliminary results for market share

\begin{tabular}{|c|c|c|c|c|c|}
\hline & \multirow{2}{*}{$\begin{array}{c}\text { Model 1 } \\
\text { market share }\end{array}$} & Model 2 & Model 3 & Model 4 \\
\hline & & & market share & market share & market share \\
\hline \multirow{11}{*}{ 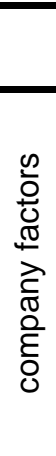 } & market share $(-1)$ & $.37230692^{* *}$ & $.38633207^{\star *}$ & $.36313714^{* *}$ & $.37460416^{* *}$ \\
\hline & export share & $.14630275^{\star}$ & $.12393125^{*}$ & $.14925332^{* *}$ & $.12404675^{\star}$ \\
\hline & efficient leadership (med) & 0.11732921 & -0.01893111 & & \\
\hline & efficient leadership (high) & 0.05839439 & -0.02286519 & & \\
\hline & professional managemen (med) & 0.10614908 & 0.13599541 & & \\
\hline & professional managemen (high) & 0.14403172 & 0.13572263 & & \\
\hline & quality management (med) & -0.13373295 & -0.12916556 & & \\
\hline & quality management (high) & -0.05043327 & -0.1371889 & & \\
\hline & price/cost reduction (med) & -0.06870013 & -0.05127158 & & \\
\hline & price/cost reduction (high) & -0.04887681 & -0.05087984 & & \\
\hline & com. tech. utilisation (high) & 0.05606763 & 0.03809587 & & \\
\hline \multirow{10}{*}{ 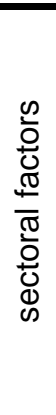 } & developed consumers (med) & 0.04241743 & & 0.07705156 & \\
\hline & developed consumers (high) & 0.04435924 & & 0.0400025 & \\
\hline & customer demandingness (med) & -0.02974793 & & -0.02007473 & \\
\hline & \begin{tabular}{|l} 
customer demandingness (high) \\
\end{tabular} & 0.01460488 & & -0.00643756 & \\
\hline & nature of comp. adv. (med) & -0.06327451 & & $-.07396457^{\star \star}$ & \\
\hline & nature of comp. adv. (high) & -0.05261131 & & -0.04147233 & \\
\hline & av. of qualified managers (med) & 0.02478145 & & -0.0085995 & \\
\hline & av. of qualified managers (high) & 0.02359289 & & -0.04986331 & \\
\hline & adeq. educated workforce (med) & -0.03397317 & & -0.03099527 & \\
\hline & adeq. educated workforce (high) & -0.13063005 & & -0.05882515 & \\
\hline \multirow{19}{*}{$\begin{array}{l}\infty \\
\frac{\omega}{0} \\
\frac{0}{\sigma} \\
\frac{0}{0} \\
\frac{0}{0} \\
\varepsilon\end{array}$} & exch. rate stability (med) & 0.04272837 & & & 0.03336346 \\
\hline & exch. rate stability (high) & 0.05268174 & & & 0.02391056 \\
\hline & EU membership (med) & $-.10031678^{*}$ & & & -0.03726161 \\
\hline & EU membership (high) & $-.13080932^{\star \star}$ & & & -0.05475907 \\
\hline & euro adoption (med) & 0.03511194 & & & 0.011402 \\
\hline & euro adoption (high) & & & & -0.00343333 \\
\hline & quality transport infr. (med) & -0.03880155 & & & -0.04100484 \\
\hline & quality transport infr. (high) & -0.05293696 & & & -0.00647698 \\
\hline & energy costs (med) & -0.01823971 & & & 0.00689463 \\
\hline & energy costs (high) & -0.03209122 & & & 0.00698967 \\
\hline & Number of observations & 352 & 402 & 363 & 399 \\
\hline & Number of groups & 58 & 64 & 60 & 64 \\
\hline & Number of instruments & 47 & 28 & 29 & 29 \\
\hline & Arellano-Bond test for $\mathrm{AR}(1)$ & -1.3633329 & -1.3231362 & -1.1277941 & -1.3613878 \\
\hline & Prob (Arellano-Bond test for AR(1)) & 0.17277762 & 0.1857901 & 0.25940688 & 0.17339116 \\
\hline & Arellano-Bond test for AR(2) & 2.0004686 & 1.9475396 & 2.1355066 & 1.9281456 \\
\hline & Prob (Arellano-Bond test for AR(2)) & 0.04544969 & 0.05147008 & 0.03271965 & 0.05383702 \\
\hline & Hansen test for over-id. restrictions & 20.555217 & 26.674225 & 23.205564 & 24.950544 \\
\hline & Prob (Hansen test for over-id. restr.) & 0.24681953 & 0.06302181 & 0.14267733 & 0.09582207 \\
\hline
\end{tabular}

Note: : Dependent variables, lagged dependent variables and quantitative explanatory variables in logarithm. Dummy variables for competitiveness factors. Two-step difference GMM estimation using xtabond2 module for Stata. Asymptotic robust standard errors are reported. Lagged dependent and differenced explanatory variables used as instruments. 


\section{ANNEX 4 Determinants OF TOTAL FACTOR PRODUCTIVITY}

Theory offers several measures of productivity. Policy makers tend to prefer simple labour productivity calculated as output per hour or output per employee. Academics favour total factor productivity (TFP), which reflects overall efficiency of transformation of inputs into output. However, both approaches have their advantages and disadvantages. TFP measure derived as a residual from a production function is more data demanding and its estimation relies on several assumptions. As stated e.g. by Sargent and Rodriguez (2001) TFP is more useful over the long run, assuming that one is confident about the underlying growth process and the quality of capital stock data.

TFP estimation based on Levinsohn and Petrin (2003) methodology requires information on value added, capital, material costs, labour costs and number of employees. The original balance sheet and financial database used throughout the paper does not include information on material costs or value added deflators. The additional data comes from the Statistical Office of the Slovak Republic. ${ }^{29}$

Following the methodology applied in the main part of the paper, we start with full specification which is finally narrowed to factor by factor analysis. Our estimates do not confirm statistically significant impact of basic company characteristics. We also do not find any specification that would satisfy our assumption of productivity being a dynamic process. $^{30}$

Preliminary analysis of significance of top company, sectoral and macro factors (identified by our earlier survey among key Slovak companies) indicate that there might be some positive impact of company management quality, price/cost reduction, or exchange rate stability on company productivity (see the table below). However, our detailed analysis does not confirm statistically significant impact of any of the analysed 15 competitiveness factors in a dynamic setting.

This does not allow us to unambiguously conclude that the competitiveness factors pointed by surveyed companies do no influence their total factor productivity. We have to keep in mind that we face a not insignificant data quality issue. We combine two not necessarily compatible financial databases and we are able to estimate total factor productivity only for one third of the surveyed companies.

\footnotetext{
${ }^{29}$ Individual company data are collected within its annual survey in production industries. Six different price deflators are used: GDP deflator for capital; energy sector deflator for material costs; industry, manufacturing industry, construction and services sector deflators for corresponding industries.

${ }^{30}$ I.e. we do not find any simple model covering only lagged total factor productivity and quantitative explanatory variable. See table 2 in section 3 for the list of used quantitative variable.
} 
Table A3 Preliminary results for total factor productivity

\begin{tabular}{|c|c|c|c|c|c|}
\hline & \multirow{2}{*}{$\begin{array}{c}\text { Model } 1 \\
\text { TFP }\end{array}$} & \multirow{2}{*}{$\begin{array}{c}\text { Model 2 } \\
\text { TFP }\end{array}$} & \multirow{2}{*}{$\begin{array}{c}\text { Model } 3 \\
\text { TFP }\end{array}$} & \multirow{2}{*}{$\begin{array}{c}\text { Model } 4 \\
\text { TFP }\end{array}$} \\
\hline & & & & & \\
\hline & TFP (-1) & -.0217809 & .16796571 & .15599542 & .11626783 \\
\hline & labour costs & $-.79101194^{\star \star \star}$ & $-.44930645^{\star \star}$ & $-.44640979^{\star *}$ & $-.49439005^{\star \star \star}$ \\
\hline \multirow{9}{*}{ 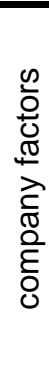 } & efficient leadership (med) & $1.6524282^{*}$ & .0396186 & & \\
\hline & \begin{tabular}{|l} 
efficient leadership (high) \\
\end{tabular} & & -.01330741 & & \\
\hline & professional management (med) & $-5.9647861^{\star \star}$ & -.09428325 & & \\
\hline & professional management (high) & -4.4295682 & $-.15180471^{*}$ & & \\
\hline & quality management (med) & $11.235669^{*}$ & -.01726633 & & \\
\hline & quality management (high) & $15.028153^{*}$ & .11157197 & & \\
\hline & price/cost reduction (med) & -2.4491841 & $.09627449^{*}$ & & \\
\hline & price/cost reduction (high) & -3.220604 & .0080598 & & \\
\hline & com. tech. utilisation (high) & $-1.7712282^{*}$ & -.03271294 & & \\
\hline \multirow{10}{*}{ 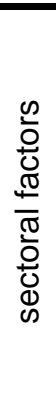 } & developed consumers (med) & -2.0662257 & & .27583235 & \\
\hline & \begin{tabular}{|l} 
developed consumers (high) \\
\end{tabular} & -1.4645996 & & .27381207 & \\
\hline & customer demandingness (med) & $-2.2094759^{*}$ & & -.23173078 & \\
\hline & customer demandingness (high) & & & -.24342639 & \\
\hline & nature of comp. adv. (med) & -2.9684671 & & -.03712046 & \\
\hline & nature of comp. adv. (high) & -1.2841446 & & -.00348587 & \\
\hline & av. of qualified managers (med) & $-1.1728052^{*}$ & & .08532087 & \\
\hline & av. of qualified managers (high) & $-6.6339132^{* \star}$ & & .3651226 & \\
\hline & adeq. educated workforce (med) & & & $-.13178674^{\star \star}$ & \\
\hline & adeq. educated workforce (high) & & & -.6961092 & \\
\hline \multirow{19}{*}{ 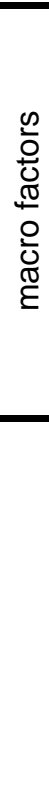 } & exch. rate stability (med) & .43112224 & & & -.05224331 \\
\hline & exch. rate stability (high) & $1.9872079^{\star}$ & & & -.11126134 \\
\hline & EU membership (med) & -.67828485 & & & .13031694 \\
\hline & EU membership (high) & & & & .09209285 \\
\hline & euro adoption (med) & .80307245 & & & -.14065789 \\
\hline & euro adoption (high) & & & & -.15610341 \\
\hline & quality transport infr. (med) & .1821879 & & & -.02262471 \\
\hline & quality transport infr. (high) & -1.370773 & & & -.02695465 \\
\hline & energy costs (med) & .77450941 & & & .07567476 \\
\hline & energy costs (high) & -1.0112604 & & & .05346352 \\
\hline & Number of observations & 111 & 133 & 111 & 133 \\
\hline & Number of groups & 27 & 32 & 27 & 32 \\
\hline & Number of instruments & 36 & 20 & 21 & 21 \\
\hline & Arellano-Bond test for $\mathrm{AR}(1)$ & 1.3867691 & -1.0395511 & -.99334011 & -1.0120724 \\
\hline & Prob (Arellano-Bond test for AR(1)) & .16551219 & .29854849 & .32054424 & .31150346 \\
\hline & \begin{tabular}{|l} 
Arellano-Bond test for $\mathrm{AR}(2)$ \\
\end{tabular} & 1.4657466 & -1.7300267 & -1.5699009 & -1.3957535 \\
\hline & Prob (Arellano-Bond test for AR(2)) & .14271734 & .08362551 & .11643817 & .16278873 \\
\hline & Hansen test for over-id. restrictions & .57263363 & 12.561777 & 8.3356827 & 11.754068 \\
\hline & Prob (Hansen test for over-id. restr.) & .9999456 & .18345826 & .50070327 & .22753151 \\
\hline
\end{tabular}

Note: : Dependent variables, lagged dependent variables and quantitative explanatory variables in logarithm. Dummy variables for competitiveness factors. Two-step difference GMM estimation using xtabond2 module for Stata. Asymptotic robust standard errors 